\title{
Akurasi dalam Mendeteksi Penyakit Kulit Menular menggunakan gabungan Metode Forward Chaining dengan Certainty Factor
}

\author{
Deosa Putra Caniago ${ }^{1}$, Sumijan $^{2}$, Julius Santony ${ }^{3}$ \\ ${ }^{1}$ J1. Raya Lubug Begalung, Lubuk Begalung Nan XX \\ ${ }^{2}$ Teknologi Informasi, Fakultas Ilmu Komputer, \\ Universitas Putra Indonesia YPTK Padang ${ }^{2}$ Fakultas Ilmu Komputer, \\ Universitas Putra Indonesia YPTK Padang \\ E-mail : deozaofficial@gmail.com, soe@upiyptk.org, juliussantony@yahoo.co.id
}

\begin{abstract}
The skin becomes the outermost protective organ for humans who most frequently interact, interactions that occur are also safe such as interactions with bacteria, viruses, fungi and parasites. This bad one can make disease. Skin diseases are often considered to be common, but in some cases skin diseases can be dangerous and deadly, further skin diseases can be contagious. Dermatologist specialists make sufferers reluctant to take part in health care. From these problems the Expert System (Expert System) was built to help patients determine the type of skin disease and the right treatment for this disease quickly based on the symptoms felt by the patient. In supporting the development of this application using the Forward Chaining (FC) Method for tracking of symptoms received by patients in the form of questions, further tracing will be processed using the Certainty Factor (CF) Method to determine the value of confidence of the type of illness suffered by the patient. The results of this study can display the types of infectious skin diseases suffered by patients, solutions and treatment of patients as well as the calculation of the Certainty Factor Algorithm (CF) the value of confidence of the type of infectious skin disease suffered. From the results of $\mathrm{CF}$ skin disease patients can determine the initial steps that correspond to infectious skin diseases using the Expert System for Communicable Skin Diseases.
\end{abstract}

Keywords: Detection, Expert System, Infectious Skin Disease, Forward Chaining, Certainty Factor

\begin{abstract}
Abstrak
Kulit menjadi organ pelindung terluar bagi manusia yang paling sering berinteraksi, interaksi yang terjadi tidaklah selalu aman seperti interaksi pada bakteri, virus, jamur dan parasit. Interaksi yang buruk ini yang dapat menjadikan terjadinya penyakit kulit. Penyakit kulit sering kali dianggap lumrah terjadi, namun dalam beberapa kasus penyakit kulit dapat menjadi berbahaya dan mematikan, terlebih lagi penyakit kulit dapat menular. Kurangnya ketersediaan tenaga medis khususnya dokter spesialis penyakit kulit membuat penderita enggan dalam memeriksa kesehatan kulitnya. Dari permasalahan tersebut maka dibangunlah sebuah Sistem Pakar (Expert System) dalam membantu pasien menentukan jenis penyakit kulit dan penanganan yang tepat bagi penyakit tersebut dengan cepat berdasarkan gejala yang diarasakan oleh pasien tersebut. Dalam mendukung pembangunan aplikasi ini menggunakan Metode Forward Chaining (FC) untuk penelusuran dari gejala - gejala yang dirasakan pasien dalam bentuk pertanyaan, selanjutnya penelusuran tersebut akan diolah menggunakan Metode Certainty Factor (CF) untuk menentukan nilai keyakinan dari jenis penyakit kulit yang diderita oleh pasien. Hasil penelitian ini dapat menampilkan jenis penyakit kulit menular yang diderita oleh pasien, solusi dan penanganan pasien serta dilakukan perhitungan Algoritma Certainty Factor (CF) nilai keyakinan dari jenis penyakit kulit menular yang diderita. Dari hasil CF pasien penyakit kulit menular dapat menentukan langkah awal yang tepat dalam menangani penyakit kulit menular menggunakan aplikasi Sistem Pakar Penyakit Kulit Menular.
\end{abstract}

Kata Kunci : Deteksi, Sistem Pakar ,Penyakit Kulit Menular, Forward Chaining., Certainty Factor 


\section{Pendahuluan}

\section{Latar Belakang}

Kemajuan dari teknologi komputer yang pesat pada saat ini sangat membantu manusia dalam segala bidang salah satunya pada dunia kesehatan. Kulit manusia menjadi organ terluar sekaligus terluar pada tubuh manusia di mana 1,5 hingga 2 meter dengan bobot $15 \%$ dari berat badan keseluruhan, yang tersusun pada 3 lapisan yaitu epidermis, dermis dan hipodermis [1]. Sehingga menjadikan kulit sebagai organ pelindung pertama bagi manusia dari berbagai macam interaksi yang terjadi. Interaksi yang terjadi pada kulit ini tidak selalu aman, contohnya interaksi bakteri, jamur, virus dan parasit.

Penyakit kulit adalah suatu kondisi yang terjadi pada lapisan luar tubuh manusia yang mengalami masalah seperti iritasi atau meradang, dimana kondisi tersebut biasanya menyebabkan kulit menjadi gatal, bersisik, perih, memerah bahkan mati rasa dan cacat. Sebagaian dari penyakit kulit ini bisa bersifat sementara, namun dalam kondisi lain bisa jadi permanen dan terus menerus kambuh [2].

Sistem Pakar adalah suatu sistem yang berbasiskan komputer yang memanfaatkan pengetahuan, fakta beserta tekhnik penalaran dari seorang pakar untuk memecahkan masalah pada bidang tertentu yang tidak dapat diselesaikan oleh orang awam [3]. Sistem pakar ini memberikan nilai lebih dari teknologi dalam bidang kesehatan pada penelitian ini sehingga dapat dijadikan alternatif kedua setelah dokter spesialis untuk pengambilan keputusan, yang pada dasarnya merupakan kondisi yang mungkin saja terjadi berdasarkan data yang akurat [4].

Kurangnya informasi yang bisa diperoleh pasien berkaitan penyakit kulit yang diderita dikarenakan banyak faktor, yaitu biaya yang mahal, ketersediaan dokter yang terbatas hingga waktu yang tidak tepat menyebabkan pasien tidak mampu menentukan jenis penyakit kulit yang berdampak pada kesalahan pada penanganan pertama yang dapat dilakukan pada penyakit kulit menular tersebut.

Dengan berkembangnya permasalahan yang ada, memberikan peluang untuk membuat suatu aplikasi Sistem Pakar mendeteksi Penyakit Kulit Menular dengan memanfaatkan kepakaran dari seorang dokter spesialis penyakit kulit kelamin untuk selanjutnya diolah dan dibuatkan sebuah sistem aplikasi.

Forward Chaining adalah salah satu mesin inferensi yang digunakan dalam Sistem Pakar, metode ini nantinya akan melakukan penelusuran melalui penalaran dari suatu masalah kepada solusi [5]. Pemanfaatan metode Forward Chaining telah banyak dilakukan pada berbagai bidan salah satunya penelitian tentang mendeteksi penyakit kulit menggunakan metode Forward Chianing dengan memanfaatkan 10 data penyakit kulit beserta 12 gejala yang ada [6].

Certainty Factor adalah suatu metode yang dapat digunakan dalam menentukan tingkat kepastian dalam suatu fakta yang ada. Sebelumnya penelitian tentang Certainty Factor juga telah dilakukan salah satunya yaitu dalam menentukan tingkat kepastian penyakit usus dengan nilai akurasi sebesar $98.46 \%$ dengan 5 data penyakit beserta 25 gejala penyakit [7].

Penelitian yang dilakukan diharapkan dapat membantu dalam menentukan dini dari jenis penyakit kulit menular sehingga dapat memberikan solusi dan pengobatan penyakit kulit menular dengan tingkat keyakinan, khususnya pada RSUD Curup Bengkulu dalam memberikan pertolongan pertama dengan tepat sebelum ditangani oleh dokter atau tim kesehatan.

\section{Rumusan Masalah}

Berdasarkan latar belakang dari masalah yang ada, maka pada penelitian ini dapat dibuat rumusan masalah sebagai berikut;

1. Bagaimana perancangan Sistem Pakar dapat mendeteksi penyakit kulit menular berbasiskan website (studi kasus di RSUD Curup,Bengkulu)?

2. Bagaimana aplikasi Sistem Pakar dengan motode Forward Chaining dan Certainty Factor dapat membantu mendeteksi dini penderita penyakit kulit menular dalam mendapatkan solusi dan pengobatan?

\section{Tujuan Penelitian}

Penelitian ini bertujuan untuk;

1. Merancang aplikasi Sistem Pakar pedeteksi penyakit kulit menular berbasiskan web.

2. Menerapkan dan menguji metode gabungan Forward Chaining dengan Certainty Factor dalam memberikan diagnosis penyakit kulit, menular, cara pencegahan dan pengobatannya. 


\section{Tinjauan Pustaka}

\section{Penyakit Kulit Menular}

Penyakit kulit termasuk penyakit yang umum terjadi dan dapat muncul secara tak terduga. Yaitu suatu kondisi yang terjadi pada saat lapisan luar tubuh mengalami masalah seperti iritasi dan meradang. Sehingga menyebabkan kulit terjangkit menjadi gatal, bersisik, memerah, luka hingga cacat. Banyak faktor yang menyebabkan kulit terjangkit penyakit kulit menular, diantaranya infeksi bakteri, virus, jamur dan parasit. Dalam diagnosis penyakit kulit sangatlah complex karena bisa jadi beberapa penyakit memiliki gejala yang sama sehingga memerlukan seorang pakar dalam bidang dermatology [8]. Berikut ini adalah jenis jenis dari penyakit kulit menular :

1. Verisella; Merupakan penyakit kulit yang biasa dikenal dengan cacar air, disebabkan oleh virus varicella zozter, di mana kondisi kulit penderita akan mengalami ruam merah pada bagian perut atau punggung

2. Skabies; Kondisi kulit yang ditandai dengan munculnya rasa sangat gatal di kulit terutama pada malam hari, dengan timbulnya ruam bintik - bintik yang menyerupai jerawat atau berbentuk lepuhan kecil yang bersisik, kondisi ini merupakan dampak adanya tungau yang bersarang pada kulit penderita.

3. Herpes Zozter; Nama lain dari Cacar Api, penyakit kulit menular yang disebabkan oleh virus dari Varicella-zoster, dapat menular melalui kontak langsung, dengan gejala awal kulit terasa terbakar sampai bintil/ruam merah muncul pada permukaan kulit, dan terus muncul mengikuti pola sumsum tulang belakang sehingga membentuk pola seperti pita mengikuti aliran saraf yang terlibat.

4. Tinea Korporis; Penyakit kulit yang disebabkan oleh dermatofi atau jamur kulit. Yang menyebabkan ruam melingkar kemerahan atau keperakan pada kulit.

5. Pitriasis Versicolor; Penyakit yang disebabkan oleh infeksi dari jamur Malassezia pada kulit yang umum terjadi, infeksi ini menggangu pigmen kulit yang membuat bercak dengan warna yang lebih terang atau lebih gelap pada kulit. Infeksi ini akan muncul secara berlahan dengan rasa gatal sehingga membentuk bercak yang lebih besar.

6. Tinea Pedis; Infeksi jamur yang menimbulkan gejala berupa ruam bersisik pada sela - sela jari kaki, sangat bersiko pada orang yang kurang memperhatikan masalah kebersihan kaki, seperti jarang mengganti kaos kaki atau menggunakan sarana umum kondisi ini dapat memperburuk keadaan dan dapat memicu peradangan pada kelenjar getah bening.

7. Morbus Hansen; Penyakit yang disebabkan oleh bakteri Mycobacterium leprae, yang menyerang saraf tepi (primer) dari kulit dan jaringan tubuh lainnya.

8. Impetigo; Infeksi kulit yang disebabkan oleh bakteri membentuk lepuhan lepuhan kecil pada kulit yang berisi nanah (pustula).

\section{Sistem Pakar}

Sistem Pakar merupakan salah satu bidang ilmu komputer yang mendayagunakan perangkat computer sehingga mampu berprilaku cerdas layaknya manusia [9]. Terdapat 2 bagian utama pada Sistem pakar dalam melakukan pengolahan pada yaitu lingkungan pengembangan (development environment) dan lingkungan konsultasi (consultation environment) yang terlihat pada Gambar1.

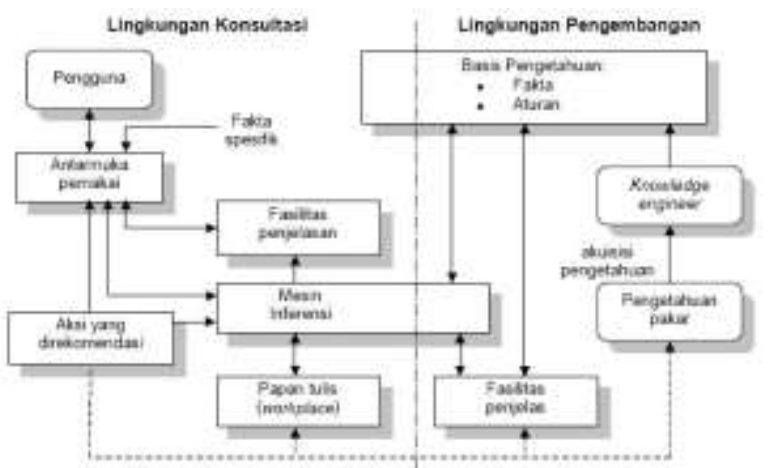

Gambar 1. Arsitektur dari Sistem Pakar

Metode Forward Chaining 
Forward Chaining (FC) adalah metode pada Sistem Pakar dalam melakukan penalaran yang dimulai dari fakta yang ada untuk mendapatkan kesimpulan dari fakta tersebut. Yaitu dengan melakukan pencocokan premis dengan fakta yang ada untuk mendapatkan fakta baru dan seterusnya hingga tercapai goal atau hingga tidak ada lagi premis yang cocok dengan fakta yang diketahui maupun fakta yang diperoleh [10]. Yang terlihat pada gambar 2 .

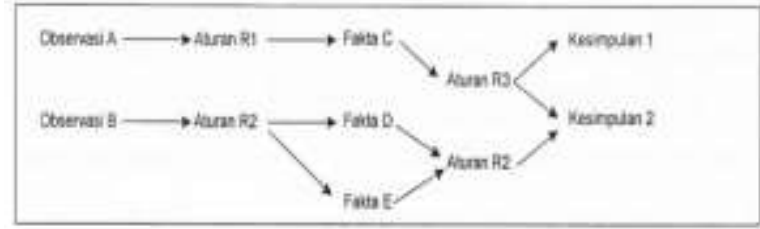

\section{Gambar 2. Proses FC}

Langkah dalam FC [11].

1. Definisi masalah berdasarkan pengetahuan

2. Definisi data input (sympthoms)

3. Definisi struktur pengendalian data (rule)

4. Penulisan awal pada basis data

5. Uji performa system

6. Pengembangan system

7. Evaluasi

\section{Metode Certainty Factor}

Certainty Factor (CF) adalah metode yang digunakan untuk membuktikan apakah suatu fakta yang ada bernilai pasti atau tidak dalam tampilan persentase. Dalam proses pengolahan metode tersebut digunakan rumus sebagai pada persamaan (1) berikut [12].

$$
\begin{aligned}
& \mathrm{CF}(\text { Rule })=\mathrm{MB}(\mathrm{H}, \mathrm{E})-\mathrm{MD}(\mathrm{H}, \mathrm{E}) \\
& 1 \quad \mathrm{P}(\mathrm{H})=1 \\
& \operatorname{MB}(\mathrm{H}, \mathrm{E})=\left\{\frac{\max [p(H \mid E), p(h)-p(h)}{\max [1,0]-p(h)}\right. \\
& 1 \quad \mathrm{P}(\mathrm{H})=0 \\
& \mathrm{MD}(\mathrm{H}, \mathrm{E})=\left\{\frac{\min [p(H \mid E), p(h)-p(h)}{\min [1,0]-p(h)}\right.
\end{aligned}
$$

Dimana :

$\mathrm{CF}($ rule $)=$ Faktor kepastian

$\mathrm{MB}(\mathrm{H}, \mathrm{E})=$ Measure of bealief, (ukuran dari nilai kepastian) terhadapat nilai hipotesis $\mathrm{H}$, jika diberikan evidence $\mathrm{E}$ (antara nilai 0 dan 1).

$\mathrm{MD}(\mathrm{H}, \mathrm{E})=$ Measure of disbealief, (ukuran dari nilai ketidakpercayaan) terhadap evidence $\mathrm{H}$, jika diberikan evidence $\mathrm{E}$ (antara nilai 0 dan 1).

$\mathrm{P}(\mathrm{H})=$ probabilitas kebenaran nilai hipotesis dari $\mathrm{H}$.

$\mathrm{P}(\mathrm{H} \mid \mathrm{E})=$ probabilitas bahwa $\mathrm{H}$ bernilai benar karena E.

\section{METODE PENELITIAN}

Metode penelitian merupakan suatu kerangka pemikiran yang menjadi gambaran dari langkah langkah kerja yang diharapkan bisa tercapai. Metode penelitian yang dilakukan pada peneltian kali ini adalah sebagai berikut;

a. Riset Lapangan

Dilakukan pengumpulan data rekam medis pasien pada poli kulit di RSUD Curup Bengkulu, dan Wawancara bersama dokter spesialis penyakit kulit dr. Ridiyah Nandasari, Sp.KK.

b. Riset Pustakaan

Dengan melakukan kajian terhadap literatur, yaitu membaca, mengulas dan menemukan kesimpulan berkaitan,,.. penelitan dari sumber bacaan buku, jurnal, media internet yang berkaitan dengan Penyakit Kulit Menular, Metode Forward Chaining dan Certainty Factor.

Kerangka Penelitian yang digunakan dapat dilihat pada gambar 3 berikut; 


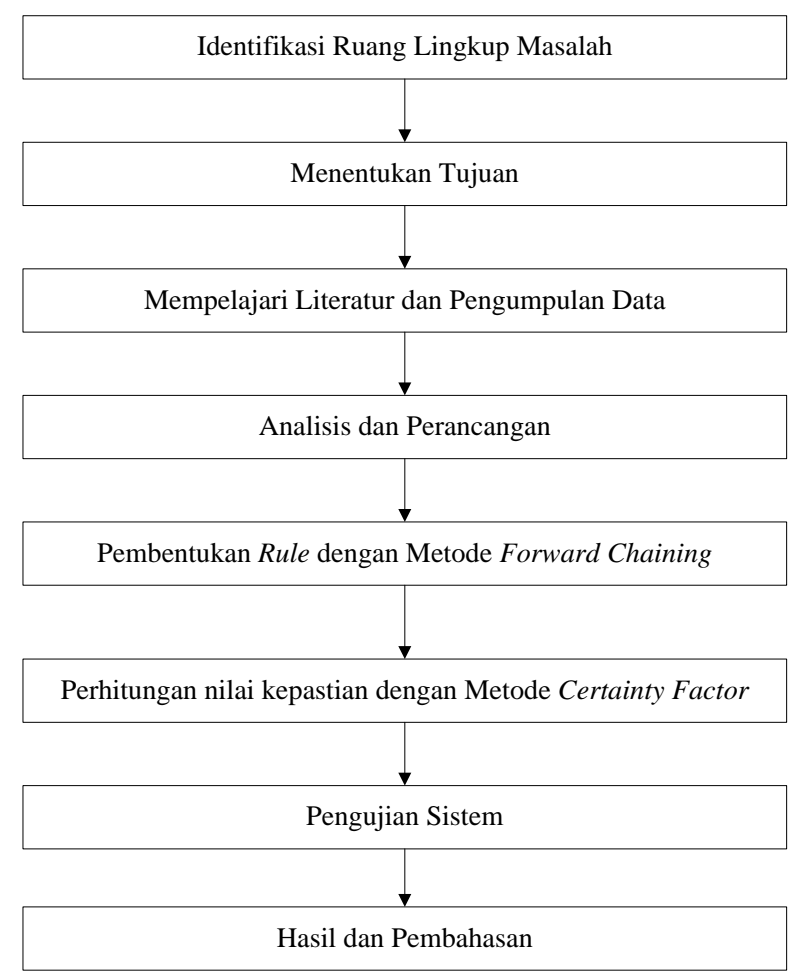

\section{Gambar 3. Kerangka Kerja}

Uraian dari kerangka kerja diatas, sebagai berikut;

1. Identifikasi Ruang Lingkup Masalah Pada tahap ini dilakukan untuk menjaga konsistensi dari penelitian, sehingga lebih terarah dan tercapai tujuan penelitian yang diharapkan. Dengan memahami masalah maka dapat ditentukan langkah penyelesaiannya untuk hasil terbaik.

2. Menentukan Tujuan Dari masalah yang muncul ditentukan tujuan dari penelitian yang dilakukan, yaitu merancang suatu aplikasi Sistem Pakar mendeteksi dini penyakit kulit menular dengan menggunakan metode Forward Chaining dan Certainty Factor.

3. Mempelajari Literatur dan Pengumpulan data. Literatur menjadi sumber acuan dalam aktivitas penelitian, dari sumber bacaan yang berkaitan tentang penelitian, setelah itu dilakukan pengumpulan data yang terkait penelitan berupa rekam medis pasien poli kulit di RSUD Curup serta wawancara kepada dokter spesialis penyakit kulit.

4. Analisis dan Perencanaan dilakukan aktivitas analisis kebutuhan sistem yang akan dibangun, berupa rancangan tampilan sampai dengan rancangan file dari system. Sehingga pasien dapat dengan mudah melakukan konsultasi menggunakan sistem yang di rancang.

5. Pembentukan rule dengan metode Forward Chaining Data yang dikumpulkan dari pakar akan diolah menjadi serangkaian aturan menggunakan metode Forward Chaining, dalam proses ini intinya memindahkan pola fikir dari pakar kedalam sebuh sistem.

6. Perhitungan nilai kepastian dengan metode Certainty Factor Setelah terbentuknya aturan tadi, selanjutnya dilakukan perhitungan menggunakan metode Certainty Factor untuk menentukan nilai kepastian dari jenis penyakit kulit yang diderita.

7. Pengujian Sistem Dilakukan pengujian sistem, dari data real kedalam sistem.

8. Hasil dan Pembahasan Penjelasan terhadap ke akuratan aplikasi yang dirancang, sehingga memberikan hasil yang sama dengan hasil manual. Dan Sistem Pakar Penyakit Kulit Menular ini layak untuk digunakan.

\section{Analisis dan Perancangan Sistem}

\section{Analisis Masalah}

Dengan adanya pengetahuan dasar tentang penyakit kulit menular memberikan kemudahan dalam menentukan langkah pertama penanganan jenis penyakit kulit menular, karena hampir setiap manusia pernah menderita penyakit kulit. Dengan dokter ahli penyakit kulit sebagai manusia memilik keterbatasan dalam memberikan informasi, seperti halnya lelah, emosi yang tidak stabil mampu mempengaruhi pengambilan keputusan. Berdasarkan permasalahan tersebut maka dicari solusi melalui Sistem Pakar ini mampu menjadi alternatif solusi untuk membantu masyarakat dalam memberikan informasi jenis penyakit kulit serta solusi yang tepat dan akurat. 


\section{Analisis Penyakit dan Gejala}

Langkah awal yang dapat digunakan dalam pengembangan Sistem Pakar ini adalah dengan mengidentifikasikan permasalahan yang dikaji. Masalah yang digunakan pada penelitian ini yaitu jenis penyakit kulit menular berserta diagnosis penyakit tersebut. Adapun data sampel yang digunakan yaitu 8 Jenis penyakit kulit menular yang paling sering diderita pada RSUD Curup Bengkulu.

Tabel 1: Data Penyakit

\begin{tabular}{|c|c|l|}
\hline NO & Kode Penyakit & \multicolumn{1}{|c|}{ Nama Penyakit } \\
\hline 1 & P01 & Verisella \\
\hline 2 & P02 & Skabies \\
\hline 3 & P03 & Herpes Zozter \\
\hline 4 & P04 & Tinea Korporis \\
\hline 5 & P05 & Pitriasis Versicolor \\
\hline 6 & P06 & Tinea Pedis \\
\hline 7 & P07 & Morbus Hansen \\
\hline 8 & P08 & Impatigo \\
\hline
\end{tabular}

Pada Sistem Pakar penyakit kulit menular terdapat 8 jenis penyakit dengan kode P01-P08.

\section{Analisis Tabel Keputusan}

Penyakit kulit menular memiliki beberapa gejala yang biasa menandai jenis penyakit yang terjangkit, pada penelitian penyakit kulit menular ini didapati 40 gejala yang menyertai 8 penyakit tersebut, seperti pada tabel 2 .

Tabel 2: Data Gejala

\begin{tabular}{|c|c|c|}
\hline NO & Kode & Nama Gejala \\
\hline 1 & G01 & Demam \\
\hline 2 & G02 & $\begin{array}{l}\text { Muncul bintik - bintik yang } \\
\text { berisi cairan (Vesikula) }\end{array}$ \\
\hline 3 & G03 & Pusing kepala \\
\hline 4 & G04 & $\begin{array}{l}\text { Terdapat Nyeri } \\
\text { Tenggorokan }\end{array}$ \\
\hline 5 & G05 & $\begin{array}{l}\text { Banyak terdapat di badan, } \\
\text { muka, kepala dan ektermitas. }\end{array}$ \\
\hline 6 & G06 & $\begin{array}{l}\text { Kulit terasa gatal saat } \\
\text { malam hari }\end{array}$ \\
\hline 7 & G07 & Muncul Kemerahan \\
\hline 8 & G08 & $\begin{array}{l}\text { Kulit terjangkit bersisik } \\
\text { halus }\end{array}$ \\
\hline 9 & G09 & Terdapat tungau \\
\hline 10 & G010 & $\begin{array}{l}\text { Terdapat di sela - sela kaki, } \\
\text { tangan, alat kelamin, } \\
\text { pinggang dll }\end{array}$ \\
\hline
\end{tabular}

\begin{tabular}{|c|c|c|}
\hline 11 & G011 & Badan lemas \\
\hline 12 & G012 & Terdapat nyeri kepala \\
\hline 13 & G013 & $\begin{array}{l}\text { Muncul gelembung } \\
\text { (veskula) yang berkelompok }\end{array}$ \\
\hline 14 & G014 & $\begin{array}{l}\text { Menyerang satu sisi tubuh } \\
\text { saja (unilateral) }\end{array}$ \\
\hline 15 & G015 & $\begin{array}{l}\text { Sering terjadi nyeri pada } \\
\text { sendi (neuralgi) setelah } \\
\text { sehat. }\end{array}$ \\
\hline 16 & G016 & Kulit terasa gatal \\
\hline 17 & G017 & $\begin{array}{l}\text { Kulit menebal dengan } \\
\text { lingkaran - lingkaran }\end{array}$ \\
\hline 18 & G018 & $\begin{array}{l}\text { Kulit terjangkit bersisik dan } \\
\text { meradang }\end{array}$ \\
\hline 19 & G019 & $\begin{array}{l}\text { Kulit terjangkit lembab dan } \\
\text { berair }\end{array}$ \\
\hline 20 & G020 & $\begin{array}{l}\text { Muncul ruam kulit yang } \\
\text { melingkar kemerahan atau } \\
\text { keperakan. }\end{array}$ \\
\hline 21 & G021 & $\begin{array}{l}\text { Terdapat rasa gatal yang } \\
\text { ringan }\end{array}$ \\
\hline 22 & G022 & $\begin{array}{l}\text { Lokasi pada dada, } \\
\text { punggung, leher, lengan atas, } \\
\text { selangkangan }\end{array}$ \\
\hline 23 & G023 & $\begin{array}{l}\text { Terdapat bercak warna putih, } \\
\text { kemerahan atau kecoklatan }\end{array}$ \\
\hline 24 & G024 & $\begin{array}{l}\text { Tampak bercak bertumpuk } \\
\text { atau bulat - bulat. }\end{array}$ \\
\hline 25 & G025 & $\begin{array}{l}\text { Semakin terlihat jika } \\
\text { berjemur }\end{array}$ \\
\hline 26 & G026 & $\begin{array}{l}\text { Terdapat luka pada sela jari } \\
\text { atau kuku jari }\end{array}$ \\
\hline 27 & G027 & Muncul bau tidak sedap \\
\hline 28 & G028 & $\begin{array}{l}\text { Bercak di sela - sela jari } \\
\text { kaki maupun tangan }\end{array}$ \\
\hline 29 & G029 & $\begin{array}{l}\text { Sering berada di tempat yang } \\
\text { lembab dan berair. }\end{array}$ \\
\hline 30 & G030 & $\begin{array}{l}\text { Sering menyerang di sela jari } \\
\text { IV \& V dan III \& IV }\end{array}$ \\
\hline 31 & G031 & $\begin{array}{l}\text { Terdapat bercak putih atau } \\
\text { kemerahan yang mati rasa }\end{array}$ \\
\hline
\end{tabular}

\begin{tabular}{|c|c|l|}
\hline NO & Kode & \multicolumn{1}{|c|}{ Nama Gejala } \\
\hline 1 & G01 & Demam \\
\hline 2 & G02 & $\begin{array}{l}\text { Muncul bintik - bintik yang } \\
\text { berisi cairan (Vesikula) }\end{array}$ \\
\hline 3 & G03 & Pusing kepala \\
\hline 4 & G04 & $\begin{array}{l}\text { Terdapat Nyeri } \\
\text { Tenggorokan }\end{array}$ \\
\hline 5 & G05 & $\begin{array}{l}\text { Banyak terdapat di badan, } \\
\text { muka, kepala dan ektermitas. }\end{array}$ \\
\hline 6 & G06 & $\begin{array}{l}\text { Kulit terasa gatal saat } \\
\text { malam hari }\end{array}$ \\
\hline 7 & G07 & Muncul Kemerahan \\
\hline 8 & G08 & $\begin{array}{l}\text { Kulit terjangkit bersisik } \\
\text { halus }\end{array}$ \\
\hline 9 & G09 & Terdapat tungau \\
\hline 10 & G010 & Terdapat di sela - sela kaki, \\
\hline
\end{tabular}




\begin{tabular}{|c|c|c|}
\hline & & $\begin{array}{l}\text { tangan, alat kelamin, } \\
\text { pinggang dll }\end{array}$ \\
\hline 11 & G011 & Badan lemas \\
\hline 12 & G012 & Terdapat nyeri kepala \\
\hline 13 & G013 & $\begin{array}{l}\text { Muncul gelembung } \\
\text { (veskula) yang berkelompok }\end{array}$ \\
\hline 14 & G014 & $\begin{array}{l}\text { Menyerang satu sisi tubuh } \\
\text { saja (unilateral) }\end{array}$ \\
\hline 15 & G015 & $\begin{array}{l}\text { Sering terjadi nyeri pada } \\
\text { sendi (neuralgi) setelah } \\
\text { sehat. }\end{array}$ \\
\hline 16 & G016 & Kulit terasa gatal \\
\hline 17 & G017 & $\begin{array}{l}\text { Kulit menebal dengan } \\
\text { lingkaran - lingkaran }\end{array}$ \\
\hline 18 & G018 & $\begin{array}{l}\text { Kulit terjangkit bersisik dan } \\
\text { meradang }\end{array}$ \\
\hline 19 & G019 & $\begin{array}{l}\text { Kulit terjangkit lembab dan } \\
\text { berair }\end{array}$ \\
\hline 20 & G020 & $\begin{array}{l}\text { Muncul ruam kulit yang } \\
\text { melingkar kemerahan atau } \\
\text { keperakan. }\end{array}$ \\
\hline 21 & G021 & $\begin{array}{l}\text { Terdapat rasa gatal yang } \\
\text { ringan }\end{array}$ \\
\hline 22 & G022 & $\begin{array}{l}\text { Lokasi pada dada, } \\
\text { punggung, leher, lengan atas, } \\
\text { selangkangan }\end{array}$ \\
\hline 23 & G023 & $\begin{array}{l}\text { Terdapat bercak warna putih, } \\
\text { kemerahan atau kecoklatan }\end{array}$ \\
\hline 24 & G024 & $\begin{array}{l}\text { Tampak bercak bertumpuk } \\
\text { atau bulat - bulat. }\end{array}$ \\
\hline 25 & G025 & $\begin{array}{l}\text { Semakin terlihat jika } \\
\text { berjemur }\end{array}$ \\
\hline 26 & G026 & $\begin{array}{l}\text { Terdapat luka pada sela jari } \\
\text { atau kuku jari }\end{array}$ \\
\hline 27 & G027 & Muncul bau tidak sedap \\
\hline 28 & G028 & $\begin{array}{l}\text { Bercak di sela - sela jari } \\
\text { kaki maupun tangan }\end{array}$ \\
\hline 29 & G029 & $\begin{array}{l}\text { Sering berada di tempat yang } \\
\text { lembab dan berair. }\end{array}$ \\
\hline 30 & G030 & $\begin{array}{l}\text { Sering menyerang di sela jari } \\
\text { IV \& V dan III \& IV }\end{array}$ \\
\hline 31 & G031 & $\begin{array}{l}\text { Terdapat bercak putih atau } \\
\text { kemerahan yang mati rasa }\end{array}$ \\
\hline 32 & G032 & $\begin{array}{l}\text { Mati rasa (ariestesi) pada } \\
\text { kedua tangan dan kaki } \\
\text { (gloves \& stocking } \\
\text { anastesia) }\end{array}$ \\
\hline 33 & G033 & $\begin{array}{l}\text { Penipisan alis mata } \\
\text { (madarosis) }\end{array}$ \\
\hline 34 & G034 & $\begin{array}{l}\text { Kelumpuhan otot mata } \\
\text { (lagophthalmus) }\end{array}$ \\
\hline 35 & G035 & Penebalan cuping telinga \\
\hline 36 & G036 & Nyeri pada kulit \\
\hline 37 & G037 & $\begin{array}{l}\text { Melepuh dengan cairan } \\
\text { kuning kemerahan }\end{array}$ \\
\hline 38 & G038 & $\begin{array}{l}\text { Cairan lepuhan membentuk } \\
\text { keropeng (erusta) }\end{array}$ \\
\hline 39 & G039 & $\begin{array}{l}\text { Pembengkakan kelenjar } \\
\text { getah bening disekitar luka }\end{array}$ \\
\hline 40 & G040 & $\begin{array}{l}\text { Jika pecah menyebar } \\
\text { disebelahnya }\end{array}$ \\
\hline
\end{tabular}

Tabel 2 menjelaskan Gejala yang digunakan pada penelitian ini sebanyak 40 data dengan pengkodean dari G01-G040.

\section{Analisis Relasi Penyakit Kulit Menular}

Setelah diketahui data yang akan diolah makan langkah selanjutnya dibuat suatu hubungan antara gejala dengan penyakit yang didapati dari RSUD Curup Bengkulu yang terlihat pada Tabel 3 sebagai berikut;

Tabel 3 Rule untu menentukan Jenis Penyakit menggunakan Forward Chaining

\begin{tabular}{|c|l|}
\hline NO & \multicolumn{1}{|c|}{ Mekanisme } \\
\hline 1 & $\begin{array}{l}\text { IF G1 is true AND G2 is true AND G3 } \\
\text { is true AND G4 is true AND G5 is true } \\
\text { AND THEN P1 }\end{array}$ \\
\hline 2 & $\begin{array}{l}\text { IF G6 is true AND G7 is true AND G8 is } \\
\text { true AND G9 is true AND G10 is true } \\
\text { AND THEN P2 }\end{array}$ \\
\hline 3 & $\begin{array}{l}\text { IF G1 is true AND G11 is true AND } \\
\text { G12 is true AND G13 is true AND G14 } \\
\text { is true AND G15 is true AND THEN P3 }\end{array}$ \\
\hline 4 & $\begin{array}{l}\text { IF G16 is true AND G17 is true AND } \\
\text { G18 is true AND G19 is true AND G20 } \\
\text { is true AND THEN P4 }\end{array}$ \\
\hline 5 & $\begin{array}{l}\text { IF G21 is true AND G22 is true AND } \\
\text { G23 is true AND G24 is true AND G25 } \\
\text { is true AND THEN P5 }\end{array}$ \\
\hline 6 & $\begin{array}{l}\text { IF G16 is true AND G26 is true AND } \\
\text { G27 is true AND G28 is true AND G29 } \\
\text { is true AND G30 is true AND THEN P6 }\end{array}$ \\
\hline 7 & $\begin{array}{l}\text { IF G31 is true AND G32 is true AND } \\
\text { G33 is true AND G34 is true AND G35 } \\
\text { is true AND THEN P7 }\end{array}$ \\
\hline 8 & $\begin{array}{l}\text { IF G16 is true AND G36 is true AND } \\
\text { G37 is true AND G38 is true AND G39 } \\
\text { is true AND G40 is true AND THEN P8 }\end{array}$ \\
\hline
\end{tabular}

Tabel 3. Menunjukan hubungan bahwasanya gejala dengan kode G6, G7, G8, G9 dan G10 adalah penyakit $\mathrm{P} 2$.

\section{Perhitungan Nilai Kepastian dengan Certainty Factor}

Pembobotan nilai MB dan MD yang telah disepakati oleh peneliti dan pakar dapat dilihat pada Tabel4 sebagai berikut:

Tabel 4 Bobot Nilai Kepastian

\begin{tabular}{l|l} 
Interprestasi & Nilai
\end{tabular}




\begin{tabular}{|l|c|}
\hline Pasti tidak & -1.0 \\
\hline Hampir pasti tidak & -0.8 \\
\hline Kemungkinan besar tidak & -0.6 \\
\hline Mungkin tidak & -0.4 \\
\hline Tidak tahu & $-0.2-0.2$ \\
\hline Mungking & 0.4 \\
\hline Kemungkinan besar & 0.6 \\
\hline Hampir pasti & 0.8 \\
\hline Pasti & 1.0 \\
\hline
\end{tabular}

Dalam tahapan ini akan digunakan suatu algoritma Certainty Factor untuk menemukan nilai keyakinan dari hasil penelusuruan rule yang didapati dari Forward Chaining. Dengan nilai MB dan MD didapati dari pakar pada rule 2 yaitu sebagai berikut; IF G6 is true AND G7 is true AND G8 is true AND G9 is true AND G10 is true AND THEN P2

\section{Nilai MB}

$\mathrm{CF}_{\text {Mbcombinel }}\left(\mathrm{CF}_{\mathrm{MBG} 06}\right.$,

$\mathrm{CF}_{\mathrm{MBG} 07}$

$=\mathrm{CF}_{\mathrm{MBG} 06}+\mathrm{CF}_{\mathrm{MBG} 07}$

$\mathrm{x}\left(1-\mathrm{CF}_{\mathrm{MBG} 06}\right)$

$=1.0+0.8 *(1-0.8)$

$=1.0+0.8 * 0.2$

$=1.0+0.016$

$=1$

$\mathrm{CF}_{\mathrm{Mbcombin} 2}(\mathrm{CF}$

Mbcombine1, $\mathrm{CF}_{\mathrm{MBG} 08)}$

$=1.0+0.6 *(1-1.0)$

$=1.0+0.6 * 0$

$=1.0+0$

$=1$
Nilai MD

$\mathrm{CF}_{\text {Mdcombine1 }}\left(\mathrm{CF}_{\mathrm{MDG} 06}\right.$,

$\mathrm{CF}_{\mathrm{MDG} 07}$

$=\mathrm{CF}_{\mathrm{MDG} 06}+\mathrm{CF}_{\mathrm{MDG} 07}$

$\mathrm{x}\left(1-\mathrm{CF}_{\mathrm{MDG} 06}\right)$

$=0.2+(-0.2 *(1-0.2)$

$=0.2+(-0.2 * 0.8)$

$=0.2-0.16$

$=0.04$

$\mathrm{CF}_{\mathrm{MDcombin} 2}(\mathrm{CF}$

Mbcombine1, $\mathrm{CF}_{\mathrm{MDG} 08)}$

$=0.04+0.2 *(1-0.04)$

$=0.04+0.2 * 0.96$

$=0.04+0.192$

$=\mathbf{0 . 2 3 2}$

$$
\begin{array}{ll}
=1.0+0 & =0.232-0.1536 \\
=\mathbf{1} & =\mathbf{0 . 0 7 8 4} \\
\mathrm{CF}_{\text {Mbcombin4 }}(\mathrm{CF} & \mathrm{CF}_{\text {Mdcombin } 4}(\mathrm{CF} \\
\text { Mbcombine3, } \mathrm{CF}_{\mathrm{MBG} 010)} & \text { Mbcombine3, } \mathrm{CF}_{\mathrm{MDG} 010)} \\
=1.0+0.8 *(1-1.0) & =0.0784+0.1 *(1- \\
=1.0+0.8 * 0 & 0.0784) \\
=1.0+0 & =0.0784+0.09216 \\
=\mathbf{1} & =\mathbf{0 . 1 7 0 5 6}
\end{array}
$$

$$
\mathrm{CF}(\text { Rule2) }=\mathrm{MB}(\mathrm{H}, \mathrm{E})-\mathrm{MD}(\mathrm{H}, \mathrm{E})
$$

$$
\begin{aligned}
& =\mathrm{CF}_{\text {MBbcombin4 }}-\mathrm{CF}_{\text {MDcombin } 4} \\
& =1-0.17056 \\
& =0.82944
\end{aligned}
$$

CF diagnosis dari penyakit Skabies (Kudis). Berdasarkan hasil dari perhitungan tersebut, maka CF dari penyakit Skabies (Kudis) adalah 0. 82944 atau $82.944 \%$.

\section{Implementasi dan Hasil}

Penerapan rancangan sistem yang telah dibuat menggunakan bahasa pemrograman PHP dengan database MySQL sebagai media penyimpanan. Berdasarkan perhitungan manual dan sistem dapat ditemukan kesamaan nilai kepastian dari setiap penyakit kulit menular yang dapat dilihat pada Tabel 4 sebagai beriut;

Tabel 4 Nilai CF yang tercapai

\begin{tabular}{|c|l|l|}
\hline NO & \multicolumn{1}{|c|}{ Nama Penyakit } & \multicolumn{1}{|c|}{ Nilai CF } \\
\hline 1 & Verisella & 0.76032 \\
\hline 2 & Skabies & 0.82944 \\
\hline 3 & Herpes Zozter & 0.746496 \\
\hline 4 & Tinea Korporis & 0.85526 \\
\hline 5 & Pitriasis Versicolor & 0.85536 \\
\hline 6 & Tinea Pedis & 0.746496 \\
\hline 7 & Morbus Hansen & 0.85536 \\
\hline 8 & Impatigo & 0.746496 \\
\hline
\end{tabular}

$\begin{array}{ll}\mathrm{CF}_{\text {Mbcombin3 }}(\mathrm{CF} & \mathrm{CF}_{\text {Mdcombin3 }}(\mathrm{CF} \\ \text { Mbcombine2, } \mathrm{CF}_{\mathrm{MBG} 09)} & \left.\text { Mbcombine2, } \mathrm{CF}_{\mathrm{MDG} 09)}\right) \\ =1.0+1.0 *(1-1.0) & =0.232+(-0.2 * \\ =1.0+1.0 * 0 & 0.768)\end{array}$

Implementasi Database 
Database yang dirancang terdiri dari lima tabel, yang terdiri dari tabel admin untuk hak akses admin sebagai pengolah data input pada sistem, tabel diagnosa yang digunakan dalam penyimpanan data penyakit kulit menular beserta kode penyakit, tabel gejala berisikan data dari setiap gejala penyakit kulit menular, tabel konsultasi yang digunakan untuk menyimpan riwayat konsultasi pengguna dan tabel relasi yang merupakan tabel penghubung untuk pembentukan rule dan pemberian bobot setiap gejala.

\section{Implementasi Interface}

Penerapan dari penilitan ini menggunakan bahasa pemrograman PHP dengan menggunakan web browser (mozilla atau google chrome) dalam penggunaanya. Pengguna dapat memilih menu dari beberapa menu form yang terdiri dari;

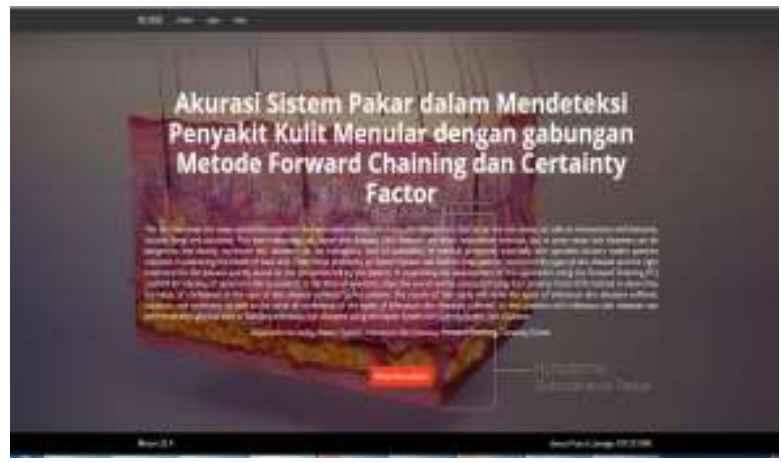

Gambar 4. Menu Awal Aplikasi

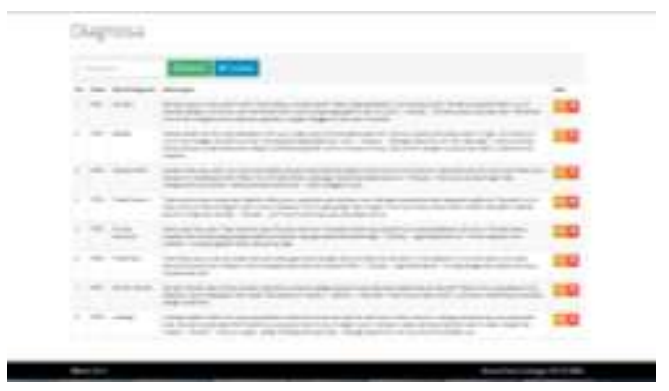

Gambar 5. Menu Penyakit

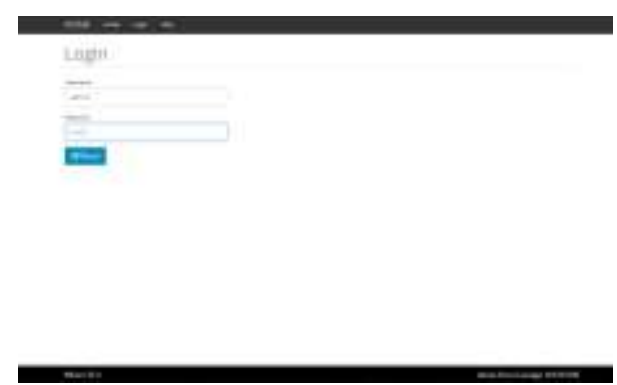

Gambar 6. Menu Login Admin

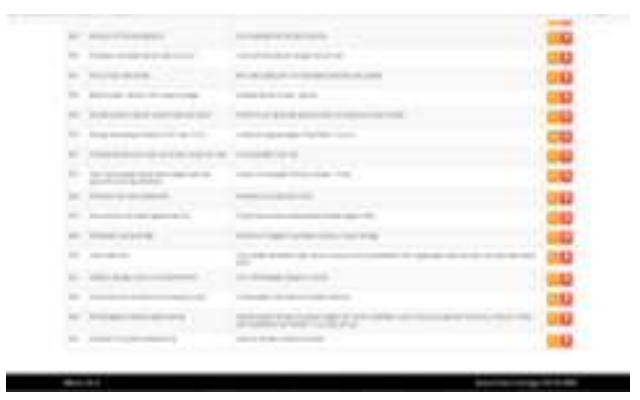

Gambar 7. Menu Gejala

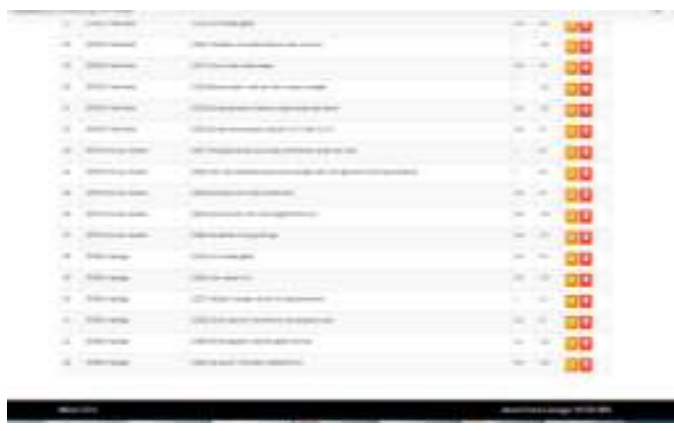

Gambar 8. Menu Bobot

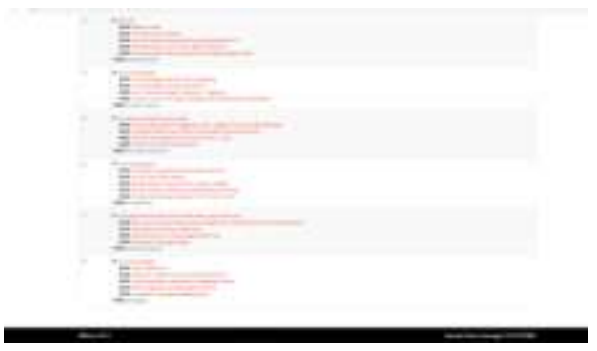

Gambar 9. Menu rule 


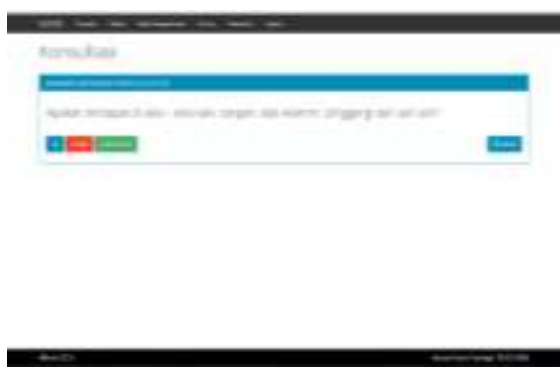

Gambar 10. Konsultasi

Gambar10 merupakan aktivitas konsultasi user terhadap sistem dengan memberikan pertanyaan berkaitan dengan gejala dan user menjawab dengan mengklik button 'Ya' dan 'Tidak' .

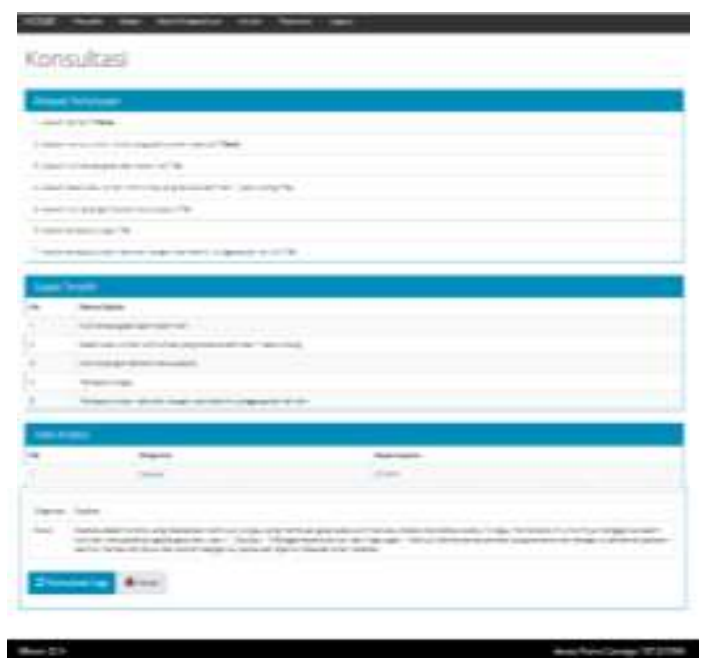

Gambar 10. Hasil Konsultasi

Gambar11 merupakan hasil dari konsultasi user terhadap sistem dengan gejala yang terpilih G6, G7, G8, G9 dan G10 hasil penyakit Skabies dengan tingkat keyakinan sebesar $82.94 \%$.

\section{Hasil}

Pada penelitian ini telah dilakukan uji coba aplikasi Sistem Pakar untuk mendeteksi Penyakit Kulit Menular kepada 20 orang user, hasil yang diperoleh dari pengujian tersebut dan dibandingkan dengan pendapat dari dokter spesialis penyakit kulit, maka diperoleh keakuratan dari sistem sebesar 100\% dari data RSUD Curup Bengkulu.

\section{Kesimpulan}

Dari hasil uraian penelitian yang telah dilaukan diatas maka didapatkan beberapa kesimpulan sebagai berikut:

1. Perancangan Aplikasi Sistem Pakar mendeteksi Penyakit Kulit Menular dapat menentukan jenis dari penyakit kulit menular sesuai dengan gejala yang dirasakan oleh user dengan metode Forward Chaining dan Certainty Factor sehingga membantu masyarakat dalam mendeteksi jenis penyakit dan menentukan langkah pertama dalam pengobatan penyakit tersebut menggunakan aplikasi website Sistem Pakar Penyakit Kulit Menular.

2. Dengan digunakannya metode Forward Chaining dan Certainty Factor sebagai alat bantu, Sistem mampu menentukan jenis penyakit kulit menular sesuai dengan kepakaran dokter spesialis dan memberikan nilai kepastian dari user yang menderita penyakit terdiagnosis dalam nilai persentase keyakinan. Dengan tingkat akurasi sistem sebesar $100 \%$.

\section{Daftar Pustaka}

[1] S. Alani, Z. Zakaria, and A. Ahmad, "Miniaturized UWB elliptical patch antenna for skin cancer diagnosis imaging," Int. J. Electr. Comput. Eng. Malaysia, 2020.

[2] W. Army, "Sistem Pakar Diagnosis Penyakit tode Forward Chaining Dan Certainty Factor,” J. Sains dan Inform., Padang, 2018.

[3] H. Hafshah, A. S. Hadisuwito \& D. M. Khairina, "Pendeteksi Gangguan Jaringan Lokal Menggunakan Metode Certainty Factor," Inform. Mulawarman J. Ilm. Ilmu Komput., Samarinda, 2019.

[4] W. Apriani \& J. Santony, "Prioritas Pengaspalan Jalan Menggunakan Metode Analytical Hierarchy Process (Studi Kasus Di Dinas PU Deli Serdang)," J. Ilm. 
Komputasi, Padang, 2019.

[5] R. Rachman, "Penerapan Sistem Pakar Untuk Diagnosa Autis Dengan Metode Forward Chaining,” J. Inform., Jakarta Selatan, 2019.

[6] J. Sundari, H. Hamimah \& P. Handayani., "Expert System to Detect Human's Skin Diseases Using Forward Chaining Method Based on Web Mobile," MATEC Web Conf., Jakarta, 2018.

[7] C. Kirana, H. A. Pradana \& R. Sulaiman, "Intestine Disease Diagnosis System Using Certainty Factor Method," Sci. J. Informatics, Pangkal Pinang, 2019.

[8] S. Naser \& A. Akilla, "A proposed expert system for skin diseases diagnosis," J. Appl. Sci. Res., Gaza Palestine, 2008.

[9] M. Minarni, I. Warman \& Y. Yuhendra, "Implementasi Case-Based Reasoning Sebagai Metode Inferensi Pada Sistem Pakar Identifikasi Penyakit Tanaman Jagung," J. Teknoif, Padang, 2018.

[10] I. H. Santi \& A. I. Septiawan, "Metode Forward Chaining Pada Sistem Pakar Dalam Mendiagnosis Penyakit Kulit," Antivirus J. Ilm. Tek. Inform., Balitar, 2018.

[11] D. T. Yuwono, A. Fadlil, \& Sunardi, "PENERAPAN METODE FORWARD CHAINING DAN CERTAINTY FACTOR PADA SISTEM PAKAR”, Kumpulan Jurnal Ilmu Komputer (KLIK), Yogyakarta, 2017.

[12] E. F. Nasution, N. A. Hasibuan \& N. Silalahi, "Rancangan aplikasi sistem pakar diagnosa penyakit pankreatitis dengan metode certainty factor,”, Majalah Ilmiah INTI, Medan, 2018.

[13] S. Sularno and P. Anggraini, "PENERAPAN ALGORITMA C4.5 UNTUK KLASIFIKASI TINGKAT KEGANASAN HAMA PADA TANAMAN PADI (Studi Kasus : Dinas Pertanian Kabupaten Kerinci)," J. Sains dan Inform., vol. 3, no. 2, p. 161, Nov. 2017. 